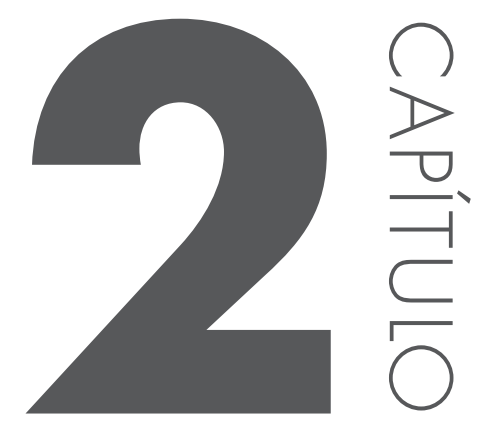

\title{
O SACRUM COMMERCIUM OU A ALIANÇA DE SÃO FRANCISCO COM A SENHORA DONA POBREZA
}

Souza, Dienes Januário de; Duarte, Teresinha Maria *

* email: teresinha_duarte@yahoo.com.br

\section{RESUMO}

A presente pesquisa teve como objetivo analisar o documento "Sacrum Commercium". De autor anônimo - a crítica o atribui a um franciscano mais erudito do século XIII ou, no mais tardar, do começo do XIV - a obra apresenta Francisco enamorado da Pobreza, a quem saúda como rainha das virtudes. Verificou-se que o autor usou amplamente o recurso da intertextualidade, o que é comprovado pelas diversas citações bíblicas, retiradas especialmente de Jó, Carta de São Paulo aos Romanos, Atos dos Apóstolos e Evangelho de Mateus. Ao mesmo tempo que faz este "jogo" literário, o autor anônimo exalta os zelanti e seu modo de vida, enquanto 
critica aqueles que se acomodaram à uma vida mais prudente e mais relaxada.

Palavras-chave: Hagiografia Mendicante; São Francisco de Assis; Literatura.

Revisado pela Orientadora Teresinha Maria Duarte, teresinha_duarte@yahoo.com.br

Souza, Dienes Januário de; Duarte, Teresinha Maria; "O SACRUM COMMERCIUM OU A ALIANÇA DE SÃO FRANCISCO COM A SENHORA DONA POBREZA", p. 29-48 . In: Seminário de Pesquisa, Pós-Graduação e Inovação da Regional Catalão (2. : 2014 : Goiás) Coletânea Interdisciplinar em Pesquisa, Pós-Graduação e Inovação - Volume 2 : Humanidades e Letras. Anais [livro eletrônico] / organizado por Adriana Freitas Neves, Idelvone Mendes Ferreira, Maria Helena de Paula, Petrus Henrique Ribeiro dos Anjos. São Paulo: Blucher, 2015. ISBN: 978-85-8039-111-4, DOI 10.5151/9788580391114-V2_Cap2 


\section{INTRODUC̣ÃO}

Este artigo é fruto de uma pesquisa, desenvolvida na Iniciação Científica, cujo plano de trabalho foi intitulado O Sacrum Commercium ou a aliança de São Francisco com a Senhora Dona Pobreza, parte de um projeto maior, cujo título é "A construção da imagem dos santos. A hagiografia mendicante do século XIII e começo do XIV”. Sacrum Commercium é uma das obras hagiográficas - vidas de santo - mendicante, isto é no âmbito das Ordens Mendicantes, produzidas dentro dentro do período acima mencionado. Portanto, a pesquisa realizada consistiu na análise da obra Sacrum Commercium. Conforme, a nossa proposta - a análise de toda a obra - trata-se de um trabalho pioneiro. Não tendo outros autores que, antes de nós, se orientassem em proposta semelhante.

$\mathrm{Na}$ historiografia em geral, bem como na historiografia franciscana, eventualmente um autor ou outro cita parte deste documento, sem se dedicar à análise do mesmo. Entre os medievalistas, especialmente André Vauchez (1985) e Brenda Bolton (1983 ) estudam a nova espiritualidade dos séculos XII e XIII. A sociedade cortês e cavaleiresca é estudada por George Duby (1989). As tensões e fraturas na Ordem dos Frades Menores ou Franciscanos é o objeto de estudo de Nachman Falbel (1995). O trabalho mais semelhante seria o de Carlos José Vieira (2008), que estudou a Legenda dos Três Companheiros, um outro documento produzido pelos radicais franciscanos do século XIII.

Trabalhamos com os seguintes objetivos: analisar o documento Sacrum Commercium, verificando como o autor representa a Senhora Dona Pobreza e corrobora com o processo da criação da imagem de São Francisco como santo pobre; verificar como aparecem, na obra, os valores humanos, cristãos e do franciscanismo primitivo; e indagar se tais valores são relevantes para a organização da sociedade, nos dias atuais.

A metodologia escolhida e utilizada foi a de revisão bibliográfica e análise da obra "Sacrum Commercium”. O exemplar usado é uma tradução, feita por Frei Dorvalino Fassini, ofm e equipe, publicada em 2002, pela Editora Mensageiro de Santo Antônio; sendo o volume 5 da coleção Fontes Franciscanas Edição de Bolso. O referido documento é de autoria anônima, sendo possivelmente escrito por algum frade afeiçoado aos primórdios do movimento franciscano e grande conhecedor das Sagradas Escrituras, em data incerta.

A seguir apresentamos os resultados da pesquisa. 


\section{RESULTADOS DA PESQUISA/DESENVOLVIMENTO}

Primeiramente, reconhecemos a tipologia do nosso documento, que é uma literatura espiritual; em seguida, identificamos a s s uas c aracterísticas: u ma literatura religiosa, que utiliza em alto grau o recurso da intertextualidade.

De acordo com Teresa Cristina dos S. A. de Oliveira (2010, p. 21-22):

O termo intertextualidade foi cunhado por Julia Kristeva, nos anos 60 , quando analisava os estudos da linguagem desenvolvidos [por] Mikhail Bakhtin. Julia Kristeva [....] diz que "a palavra (o texto) é um cruzamento de palavras (de textos), onde se lê, pelo menos, uma outra palavra (texto). É com essa frase que Kristeva cunha, elabora e fixa o conceito de intertextualidade, dizendo que um texto é um conjunto de enunciados, tomados de outros textos, que se cruzam e se relacionam ou que "todo texto se constrói como mosaico de citações, todo texto é absorção e transformação de um em outro texto".

O intertexto é um texto que está presente dentro de outro texto. De acordo com a mesma autora, há diferenças nas formas e graus de intertextualidade, podendo esta ser manifestada de forma explícita ou implícita. Dentro da manifestação explícita de intertextualidade existem três formas, sendo a epígrafe, citação e a referência. A epígrafe é utilizada para introduzir o leitor numa prévia do que o espera no decorrer da leitura; a citação é o modo mais evidente da intertextualidade, visto que deixa claro para o leitor que houve o empréstimo de ideias de outro texto para o texto no qual se está lendo; a última manifestação é a referência onde o autor cita de maneira direta o trabalho de outro, permitindo ao leitor fazer relações entre as duas obras.

Já dentro da manifestação implícita existem seis formas, sendo a alusão, eco ou traço, paráfrase, paródia, ironia, pastiche. A alusão pode ser caracterizada como uma menção que pelo uso da referência ou da citação, sendo uma manifestação consciente e intencional de outra obra; o eco ou traço sugere uma manifestação inconsciente de citar um texto em outro de maneira não intencional; a paráfrase ocorre quando o autor interpreta um texto e o reescreve em outro texto com suas palavras; a quarta manifestação é a paródia que ocorre quando se tem uma composição pronta de um texto e o autor modifica algumas partes, na maioria das vezes sendo cômica, porém sendo fiel à estrutura original. A manifestação implícita de ironia permite que tenha o paradoxo na escrita, ou seja, escrevendo um texto de forma contrária do que ele 
representa, em suma permite fazer um contraste entre aparência e realidade. A última forma de manifestação implícita é o pastiche, sendo considerado como uma falsificação, onde um autor se apodera de um trabalho desenvolvido por outro autor e o trata como se fosse seu.

Sacrum Commercium possui intertextualidade tanto explícita quanto implícita, nas formas de: citações, referências, alusões e paráfrases. As Sagradas Escrituras são o intertexto, por excelência, no interior de todo o nosso documento. O escopo da obra é exaltar os primórdios franciscanos, sobretudo a relação com a Pobreza. Já no Prólogo, o autor anônimo abre a sua obra enaltecendo-a.

Entre as demais preclaras e precípuas virtudes que preparam no homem um lugar e uma morada para Deus e mostram o caminho mais excelente e mais rápido para se ir e chegar até ele, destaca-se a Santa Pobreza. Ela sobressai a todas por uma certa prerrogativa e supera os títulos das demais por uma graça singular. Pois ela própria é o fundamento e a guardiã de todas as virtudes (Mt,7,24). E, entre as outras virtudes evangélicas ela tem merecidamente a primazia, tanto quanto ao nome, como ao lugar. Não há, pois, razão para que as demais temam as chuvaradas, as enchentes e os furacões ameaçadores de ruína se estiverem estabelecidas sobre esta base (Com, 1). Obs.: Entre os especialistas neste tipo de literatura, usase uma abreviação da obra, Sacrum Commercium (Com), seguida de vírgula e o número referente ao capítulo. Portanto, toda vez, neste artigo, que ocorrer a citação de trecho da obra, será usada a abreviatura Com, seguida do número do capítulo.

Verificar a presença da intertextualidade presente no documento, quando o autorao cita a passagem de Mt 7,24, comparando a Pobreza com a rocha que dá sustentação às demais virtudes, como um alicerce. Quem a possui terá também alcançado as demais virtudes. Ao longo de todo o Prólogo, o autor anônimo destaca a importância da Pobreza. Concluindo-o, apresenta São Francisco:

[...] como verdadeiro imitador e discípulo do Salvador no principio de sua conversão dedicou-se com todo o empenho, com todo o desejo e com toda a deliberação a procurar, encontrar e conservar a Santa Pobreza, nada duvidou de adverso, nada temeu de sinistro, não se esquivou de nenhum labor, nem declinou de nenhuma 
angústia corporal, se lhe fosse dada apenas a possibilidade de chegar aquela a quem o Senhor entregou as chaves do Reinos do céus (Mt. 5,3; 16,19) (Com, 4).

De acordo com Falbel $(1995$, p. 6) a entrega de Francisco a uma vida pobre fez com que ele fosse comparado a Cristo, o qual também viveu uma vida simples e sem riquezas. Um momento forte da conversão de Francisco foi quando beijou um leproso; depois disso ele abriu mão de sua riqueza para viver como pobre e com os pobres, imitando o Cristo pobre do Evangelho. Francisco inicia a sua busca pela Pobreza, "como um explorador curioso, ele começou a rondar pelos becos e praças da cidade, procurando diligentemente a que era a amada de sua alma. Interrogava os que estavam parados, perguntava aos que chegavam, dizendo: Será que não vistes aquela que minha alma ama? (Com, 5)".

Quando a encontrou, ficou d eslumbrado c om e la. $\mathrm{N}$ a s ua 1 inguagem cavaleiresca, a Pobreza era a Senhora Pobreza, esposa de Cristo, seu senhor. Por isto, como nas relações cavaleirescas entre o moço, o senhor e a dama (DUBY, 1989, p. 64). Na qualidade de vassalo fiel, Francisco se coloca todo ao seu serviço. Entretanto a Pobreza não era bem vista. As pessoas viam-na como uma desgraça e "[...] odiavam-na veementemente, como fazem até hoje, e sobre ela não podiam falar nada de pacífico ao que perguntava; por isso responderam como a um estranho, afirmando que não sabiam nada do que se estava perguntando" (Com, 5).

Por isto, Francisco foi tratado como alucinado pelo seu próprio pai, seus amigos e a população; até mesmos os sábios, conforme o capítulo $6^{\circ}$ de Sacrum Commercium, escandalizaram-se com sua busca pela Pobreza “Que espécie de nova doutrina é esta que trazes aos nossos ouvidos?" Com efeito, grupos adeptos da pobreza - as heresias, isto é os grupos dissidentes, dentro da Igreja, especialmente nos séculos XII e XIII, que a criticavam veementemente pelo seu luxo e riqueza - vinham crescendo em toda a Idade Média causando alvoroço na Igreja.

Ainda, na sua procura pela Senhora Pobreza, dois anciãos indicam a Francisco que "ela subiu a um grande e alto monte, onde Deus a revestiu de glória"' (Ap 21,10; Mt 28,16 Apud Com, 10). A imagem do monte remetida aos livros de Apocalipse e Evangelho de Mateus, retoma a simbologia do encontro com Deus, da proximidade com o Divino. Grandes personagens bíblicos como Abrão, Moisés, Elias e o próprio Jesus Cristo têm uma relação com Deus, nestes lugares, nos cimos dos montes. Quando é indicado a Francisco que a Pobreza habita o monte é o mesmo que 
dizer que ele a encontrará junto de Deus no monte; logo, encontrá-la, é encontrar-se com o Divino.

$\mathrm{E}$, aqueles anciãos the orientaram sobre a necessidade do despojamento total e da necessidade de ter companheiros consigo, pois a subida ao monte, para o encontro com a Pobreza era árdua e difícil (cf. Com, 11). Francisco tomou companheiros consigo (cf. Com, 12). Entretanto, logo, alguns entre eles “[...] comentavam entre si dizendo: 'Quem conseguirá subir neste monte e chegar até ao seu cume?' " (Sl 23,3 apud Com,12). Não obstante as dificuldades, subiram o monte a passos rápidos, o que levou a Pobreza a se admirar, dizendo: "Já faz tempo que não vejo pessoas assim, nem vi tão expeditas por terem jogado fora até todos os pesos" (Com, 14). Francisco e seus companheiros, então, imploram-lhe:

Ouvimos dizer que és a rainha das virtudes e, de qualquer maneira, foi isso que aprendemos com a experiência. Por isso, prostrados aos teus pés, suplicamos humildemente que te dignes estar conosco e sejas para nós o caminho que leva ao rei da glória, como foste caminho para Ele, quando se dignou visitar [...],os que jaziam nas trevas e na sombra da morte (Lc 1,78 apud Com 16).

Foi por meio da Pobreza, rainha das virtudes, que Jesus Cristo, o Filho de Deus, despiu-se de sua riqueza e de sua glória para vir até aos humanos, trazerlhe a salvação. Novamente, fazendo uso da linguagem cavaleiresca da sua época, o autor fala: "o Filho do altíssimo Pai se enamorou dos teus encantos" (Com, 19). Com efeito, Jesus iniciou a sua vida já em contato com a pobreza, nascendo em uma manjedoura. Em um de seus primeiros ensinamentos, afirmou: "Bem-aventurados os pobres em espírito, porque deles é o reino dos céus (Mt 5,3)", louvando a Pobreza e aqueles que a ela seguiam. A exaltação que Cristo faz da pobreza, acontece também, na sua escolha dos discípulos, visto que os escolheu entre os pobres. A Pobreza foi, para Jesus Cristo, uma companheira fiel, até quando todos $\mathrm{O}$ abandonaram, Ele pode contar com ela. Como um vassalo e uma esposa fiel, a Pobreza o acompanhou até à Cruz. Por ficar com Ele nos momentos mais difíceis, ganhou um lugar especial no seu coração, sendo reverenciada, louvada e honrada por Ele. Assim, ante as súplicas de Francisco e de seus companheiros (Com, 22), a Pobreza se afeiçoa a eles e com eles reparte seus conselhos.

Então, a Pobreza começa a contar-lhes a sua história, a qual se confunde com a História da Salvação. "Estive, uma vez, no paraíso de Deus (cfr. Ap 2,7), onde estava o homem nu e até passeando naquele belíssimo jardim (cfr. Gn 
$2,25 ; 3,8)$, sem temer nada, sem duvidar de nada, e sem suspeitar de nenhuma coisa adversa" (Com, 25). Nota-se que a nudez tratada neste momento não se refere à falta de pudor, mas sim, à Pobreza total e ao total despojamento. Entretanto, a desobediência a Deus leva à vergonha de ficar nu, o que pode ser entendido como o desprezo à Pobreza. Desde então, a Pobreza ficou sem descanso e sem dignidade. Sua dignidade só foi novamente reconhecida, com a vinda de Cristo à terra, quando a tomou por companheira fiel e a deixou como “testamento" (Com, 31) nas várias orientações que o Senhor dá, no Evangelho, aos seus seguidores. Tais orientações, a Pobreza reconhece que foram seguidas com esmero pelos Apóstolos (Cf. Com, 32).

Vale ressaltar que, como demonstrou Grégoire (1972, p.395-409), os adeptos da nova espiritualidade nos séculos XII e XIII tinham como preocupação seguir nu o Cristo nu (nudus nudum Christum sequir) e evangelizar os pobres, o que ficou conhecido como abraçar à vita apostólica. De acordo com Vauchez (1995, p. 74), a compreensão da vita apostólica, ao tempo de Francisco, implicava superar as diferenças entre pobres e ricos e exigia daqueles que queriam seguir o Evangelho ao pé da letra viver como pobres, por causa de Cristo que também viveu pobre. Segundo o mesmo autor (VAUCHEZ, 1995, p. 74), a austeridade e a pobreza material foram, as maiores preocupações dos grupos que perseguiam esse ideal.

Com efeito, a fidelidade ao exemplo de Cristo e dos Apóstolos perdurou nos primeiros tempos do Cristianismo. A Senhora Pobreza recorda que "Esta vitória perdurou por um tempo muito longo, de maneira que cada dia mil milhares eram marcados com o sinal do Rei altíssimo (cf. Ap 7,3-8)" (Com, 33). Entretanto, recorda:

Mas ai! Depois de pouco tempo fez-se a paz, e essa paz foi pior que qualquer guerra: no princípio, foram poucos os assinalados; no meio, menos ainda; e no fim, pouquíssimos. E agora, certamente, eis que na paz está a minha maior amargura (cfr. Is 38,17), nela todos fogem de mim, todos me afugentam, não sou procurada por ninguém, por todos sou abandonada. Estou em paz com os inimigos, mas não com os de casa, [...] (Com, 34).”

Como se percebe através da citação acima, os cristãos que, antes, eram pobres, desde a Paz Constatiniana - trata-se do reconhecimento feito pelo Imperador Constantino, em 313, que passou a considerar o Cristianismo como religião lícita no Império Romano, o que fez cessar as perseguições contra os cristãos - se esqueceram do Cristo pobre e, aos poucos, foram abandonando 
aquele estilo de vida mais austero. Situação que a Senhora Pobreza se lembra com tristeza: "[...]o diabo estava em muitos que estavam comigo, maltratandoos, e o mundo aliciava-os, a carne tentava-os, de modo que muitos começaram a amar o mundo e as coisas que estão no mundo (1Jo 2,15)" (Com, 35). A Pobreza passou a ser rejeitada e passou a ser vista como fraqueza; sendo por conta disto esquecida e desprezada. Nos tempos que se seguiram à Paz Constantiniana, até sua irmã, a Perseguição, lhe abandonou:

[...] minha irmã me abandonou (Lc 10,40) [...] [e], enquanto a paz era dada pelos perseguidores aos meus filhos, eles se estraçalhavam em luta doméstica e interna, invejando-se mutuamente, provocandose mutuamente $(\mathrm{Gl} 5,26)$ na aquisição de riquezas e na torrente de prazeres (Com, 36).

Assim, o sentimento entre significativas parcelas da sociedade europeia ocidental, a partir do século XII, percebia percebia-se que a Igreja havia se afastado da austeridade dos primeiros tempos, até clérigos e religiosos se digladiavam pelo poder e pelas riquezas. A começar pelos cluniacenses, grupos clamavam por uma reforma. Segundo Gonzalez (2011, p. 341):

Ao sonho de uma reforma geral de acordo com o modelo monástico, somaram-se outros que, sem serem todos cluniacenses, participavam dos mesmos ideais. Em contraste com a corrupção que existia $\mathrm{cm}$ quase toda a igreja no século X e no princípio do XI, o movimento cluniacense e outros que seguiram o mesmo padrão pareciam ser um milagre, um novo amanhecer em meio às trevas.

Algumas daquelas tentativas de reforma vieram a se constituir em novas ordens monásticas como foi o caso de cluniacenses e cistercienses; outras em ordens de cônegos regrantes, como os Cônegos de Santo Agostinho. Daqueles reformadores, a Pobreza tece uma série de elogios ao longo do capítulo 37. Todos eles se tornaram íntimos seus e se relembra com gozo: "Minha alma estava grudada com eles e havia em nós um só espírito e uma só alma (cf. Ef 4,4-5)" (Com 37). Entretanto, do fervor dos fundadores ao processo de institucionalização das novas ordens religiosas, a Pobreza ia ficando esquecida. Situação que ocorreu entre os Cluniacenses, os Cônegos Regulares e até entre os Cistercienses, segundo Bolton (1983, p. 40-44), os mosteiros estavam mais preocupados com a forma do que com o espírito, se esquecendo da Pobreza. De acordo com Bolton (1983, p. 45-46), 


\begin{abstract}
O ideal principal da espiritualidade, que os reformadores monásticos tinham sempre tendência para procurar nas condições da sua época, continha uma grande imprecisão quanto à questão da pobreza e à dificuldade de a definir. Se era evidente que o monge que queria ser "pobre de espírito" tinha que extirpar completamente o vício da propriedade pessoal, qual devia ser o grau deste "despojamento" e que forma podia tornar a sua vida pura no seio de uma comunidade que era, ela própria, frequentemente rica?
\end{abstract}

A Senhora Pobreza percebe que é Avareza a causadora do vício da propriedade mencionada, mencionado pela autora; , mas os falsos religiosos o chamam de Sabedoria ou Previdência; indignada a Senhora Pobreza completa: “[...] assim mesmo impuseram-lhe o nome (cfr. Dt 22,17) de Discrição ou Providência, ainda que fosse melhor chamar essa discrição de confusão" (Com, 39). De fato, à medida que suas terras e serviçais produzem mais e entesouram mais, tornaram-se operários que puseram a mão no arado, mas olham para trás. Nos capítulos subsequentes (40, 41, 43, 44, 45, 46, 47, 48, 50), a Pobreza fala daqueles que tinham propósitos santos e de amor para com ela, entretanto, foram vencidos pela Avareza, que, muito honestamente, tomou o nome de Discrição e Previdência. Mal que acometeu muitos daqueles que estavam inseridos nos propósitos de reforma da Igreja e haviam até aderido aos programas da vita apostólica, inclusive, entre os próprios Menores.

Entre eles próprios, a princípio seguidores da Altíssima Pobreza, mas sabemos que especialmente em torno dos anos de 1220, as tensões no interior da fraternidade minorítica - fraternidade dos Frades Menores, encabeçada por São Francisco de Assis -, estavam cada vez mais maiores. No Capitulo Geral de 1221, “[...] Francisco apresentou o texto da Regra Prima ou não Bulada, a qual foi rejeitada pela maioria dos frades, porque muito dura de ser observada. Foi-lhe pedido que redigisse novo texto" (DUARTE, 2004, p. 75). A Legenda Perusina conta que, naquele Capítulo, uma comissão de ministros foi pedir ao Cardeal Hugolino que convencesse o Fundador de aceitar a Regra de São Bento ou de Santo Agostinho ou de São Bernardo por que impõem uma pobreza individual, mas permitiam que o mosteiro tivesse rendas, que garantisse uma certa segurança à comunidade monástica. Francisco tomando o Cardeal pela mão, diante da assembleia, rejeita esta hipótese, veementemente, afirmando:

Irmãos meus, irmãos meus, Deus me chamou pelo caminho da humildade e me mostrou o caminho da simplicidade: não quero que 
me falem de nenhuma Regra, nem de S. Agostinho, nem S. Bento nem de $\mathrm{S}$. Bernardo. $\mathrm{O}$ senhor me disse que queria que eu fosse um novo louco no mundo; e Deus não quer conduzir-nos por outro caminho senão por esta sabedoria. Pela vossa ciência e sabedoria, Ele vos confundirá. [...] Então o Cardeal ficou estupefato e calado; e os frades todos cheios de medo (LP 114).-

Francisco rejeitou, com isto, toda a monasticização de sua fraternidade e todas as seguranças que ela poderia oferecer, para ser "um novo louco no mundo", encantado - como nas novelas cavaleirescas - com a esposa do seu Senhor, isto é com a Senhora Pobreza. A Regra de Francisco é o Evangelho, especialmente, aquelas partes nas quais o Senhor ensinou e mandou aos seus discípulos que vivessem em pobreza, como o atesta o próprio Sacrum Commercium, no capítulo 31.

Após a morte de Francisco, a situação havia ficado mais tensa no interior da fraternidade. Teresinha Duarte (2004, 85-89) afirma que Frei Elias continuou governando a Ordem até o Capítulo de 1227, quando foi eleito, para a função de ministro geral o provincial das Espanhas, Frei João Parente. Sobre Frei Elias pesava uma série de descontentamentos e a resistência de um número considerável de frades, especialmente dos companheiros do Santo que ainda viviam. O generalato de Frei João Parente foi marcado por questões cruciais: a canonização de São Francisco; a realização do capítulo geral de 1230 em meio a muitas conturbações, como os desencontros em torno do translado do corpo de São Francisco; a resistência da facção ligada a Frei Leão ante o processo de evolução, que transformava a fraternitas em uma Ordem de clérigos.

Gregório IX (anteriormente Cardeal Hugolino) canonizou, isto é reconheceu-o com santo elevou Francisco à honra dos altares, logo a 26 de julho de 1228 e, naquela ocasião incumbiu Frei Elias da construção de uma igreja em honra do Santo, onde se construiria um túmulo especial, para o qual os sagrados despojos deveriam ser transladados. O translado foi marcado para o dia 25 de maio de 1230, coincidindo com o Capítulo Geral, a ser celebrado na festa de Pentecostes daquele ano. Entretanto, o tal evento que deveria ter sido um acontecimento especial para a Ordem e para a cidade de Assis, aconteceu em meio a situações não esclarecidas, gerando muito mal estar. Naquele Capítulo, também, aconteceu que partidários de Frei Elias tentaram exigir a renúncia de Frei João Parente, tumultuando a assembleia. Naqueles anos, também, se consolidava uma facção liderada por Frei Leão, os zelosos defendiam que o Testamento de São Francisco deveria ser observado literalmente, da mesma forma que a Regra. Esta facção veio a se consolidar no grupo dos zelanti. 
Se havia uma facção de frades zelosos, havia outra interessada em suavizar o programa do Fundador e alegava pontos confusos na Regra. Para esclarecer os pontos confusos quanto à observância da Regra e do Testamento, foi formada uma comissão para ir ao Papa elucidar aqueles pontos. Depois de ouvir aquela comissão, Gregório IX anunciou a sua decisão, por meio da bula Quo elongati, que foi a primeira interpretação pontifícia da Regra de São Francisco. Sobre esta bula pontifícia e seus efeitos, conclui Duarte (2004, p. 89):

Elaborada no sentido de trazer a concórdia no interior da Ordem, a Quo elongati foi um duro golpe para os zelanti, para quem era difícil aceitar as interpretações dadas à Regra e à decisão acerca do Testamento, que, indiretamente permitia não apenas o uso mas também as seguranças que o dinheiro oferece. Por outro lado, a citada bula favorecia a institucionalização e a clericalização da Fraternidade, transformando-a em uma ordem de pregadores. De qualquer maneira, terminava a fase heróica, em que predominou o ideal, para dar lugar aos interesses da instituição - ou ao menos, diríamos, para ser mais condizente com a realidade de cada dia.

Sem dúvida, um duro golpe para os zelanti, mas não a destruição dos mesmos que nos anos subsequentes se mantiveram bastante ativos e arregimentando outros para a sua causa, sobretudo por meio da produção escrita, como em hagiografias sobre São Francisco, como o é o caso da Legenda dos Três Companheiros, analisada por Carlos José Vieira (2009). Na análise deste documento, o autor concluiu:

Os autores da Legenda enfatizaram a imagem de Francisco extremamente pobre, fraterno e pregador, pois queriam perpetuar as relações entre os irmãos com as características dos primeiros tempos, uma vez que, à altura em que escreviam, fortes transformações ocorriam e a fraternitas dava lugar a uma Ordem religiosa com características clericais, situações que nem sempre preservavam os laços fraternos, como foram vividos nos tempos heroicos da fraternitas franciscana (VIEIRA, 2009, p. $68)$.

Assim, no capítulo 42 do Sacrum Commercium, o autor coloca na boca da Pobreza um reconhecimento dos "bons religiosos". Elogio, por certo, dirigido aos zelanti. Estavam entre eles os primeiros companheiros do Santo, ainda sobreviventes, como era o caso de Frei Leão, Frei Bernardo, Frei Gil, Irmã Clara, 
dentre outros. Tinham resistido às tentações vindas em nome da Discrição e da Previdência. "[...] eles batiam às portas do céu com clamores e entravam pela insistência das orações, superando-se na contemplação, desprezando todas as coisas terrenas" (Com, 42).

Voltando à sequência dos capítulos da obra, o capítulo 52 coloca na boca divina um discurso um tanto pessimista com relação à observância da pobreza, o que retrata as dificuldades vividas pelos frades adscritos à Regra, na década de 1230, com o retorno de Frei Elias ao generalato e à perseguição que moveu aos primeiros companheiros do Santo, enquanto a evolução da fraternitas progredia para uma ordem de clérigos.

Segue-se nos capítulos seguintes $(53,54,55,56$ e 58), o diálogo entre a Senhora Pobreza, o Bem-aventurado Francisco e seus companheiros, culminando na aquiescência daquela Senhora em descer a montanha com eles, para ir aonde eles moravam (capítulo 59). Logo que chegaram, ela indaga:

Mostrai-me antes a capela, a sala do capítulo, o claustro, o refeitório, a cozinha, o dormitório e o estábulo, as cadeiras bonitas, as mesas bem lisas e as casas enormes. Pois não estou vendo nada disso; só o que vejo sois vós, alegres e felizes, transbordando de gozo, cheios de consolação (cfr. 2Cor 7,4), como se esperásseis que é só desejar e vos darão tudo.

Eles responderam dizendo: "Senhora e rainha nossa, nós, os teus servos, estamos cansados da longa viagem; e enquanto viestes conosco, também fizeste um grande esforço. Vamos então primeiro comer, se te agrada, e assim reforçados vamos fazer tudo conforme os teus planos (Com, 59).

Ela concorda, mas pede água para lavar as mãos e toalhas para secá-las. Então:

Trouxeram logo meio vaso de barro cheio de água, porque não havia ali um inteiro. Despejaram-na nas mãos dela, enquanto olhavam para cá e para lá, buscando uma toalha. Como não a encontraram, um deles ofereceu-lhe a túnica que vestia para enxugar as mãos. Ela, recebendo-a agradecida, louvava a Deus em seu coração, por tê-la unido a tais homens de valor (Com, 60).

Quando se dirigem à mesa: 
[...] [a Pobreza] olhou ao redor e não vendo mais do que três ou quatro pedaços de pão de cevada ou farelo colocados na grama, ficou m uito a dmirada, dizendo c onsigo: Q uem j amais viu e ssas coisas nos séculos que passaram (cfr. Is 66,$8 ; 51,9$ )? Bendito sejas, Senhor Deus (cfr. 1Cr 29,10; Lc 1,68), que cuidas de tudo (cfr. Sb 12,13); pois, quando queres, podes usar o poder (cfr. Sb 12,18); com essas obras, ensinaste o teu povo (cfr. Sb 12,19) a te agradar". Assim assentaram-se juntos, dando graças a Deus (cfr. $\mathrm{Cl} 3,17)$ por todos os seus dons (Com, 61).

Hóspede exigente, ela pede a comida em travessas, ao que os frades “ [...] trouxeram uma travessa cheia de água fria, para que nela todos molhassem o pão: ali não havia nem uma quantidade de travessas nem variedade de alimentos" (Com, 62). Quando ela lhes pede verduras, como não tinham nem jardineiro e nem hortelão, trazem-lhe ervas silvestres; ante o pedido de sal, para temperálas, pediram para ir à cidade esmolá-lo e com relação às facas, concluíram que era melhor usar os dentes. Quando ela lhes pediu o vinho, justificaram que o melhor para "[...] a vida do homem é a água e o pão" e que ela, como esposa de Cristo deveria evitá-lo (o vinho), “[...] como se fosse veneno” (Com, 62)

Satisfeitos com aquela refeição:

[...] mais pela glória de tanta privação do que ficariam pela abundância de todas as coisas, bendisseram ao Senhor, diante do qual encontraram tanta graça, e levaram-na para um lugar em que pudesse repousar, porque estava cansada. E assim jogou-se despida sobre a terra nua. Pediu também um travesseiro para sua cabeça. Trouxeram logo uma pedra e colocaram embaixo dela (Com, 63).

Depois de refeita na mesa fraterna e no repouso, São Francisco e seus companheiros "Conduziram-na [a Senhora Pobreza] para uma colina e the mostraram todo o mundo que podiam ver, dizendo: "Senhora, este é o nosso convento" (Com, 63). Tem-se nestes últimos capítulos do documento o seu ápice, a defesa de uma vida pobre, fraterna e extremante livre: o mundo todo é o seu convento. Desapegados das comodidades das grandes cortes e mosteiros, se alimentado do que encontravam ou do que lhos dessem, repousando, muitas vezes, ao relento, como nos tempos heroicos da fraternidade, cultivavam os insignes valores da pobreza, da fraternidade entre si e entre todas as coisas e gozavam da mais plena liberdade. Sentiam-se homens verdadeiramente livres, pois o mundo todo era o seu convento. Onde quer que estivessem se sentiam em casa. 
Finalizando, nos capítulos 64 a 69, a Senhora Pobreza, muito satisfeita com o que viu, abençoa Francisco e seus companheiros:

Na verdade, o Senhor está convosco e eu não sabia (cfr. Gn 28,16). Eis que já vejo o que almejei, já tenho o que desejei, porque me uni na terra aos que representam para mim a imagem daquele com quem estou desposada nos céus. Que o Senhor abençoe a vossa fortaleza e receba as obras de vossas mãos (cfr. Dt 33,11) (Com, 64).

Notar a alegria da Senhora Pobreza em verificar naqueles homens a imagem de Cristo, por sua pobreza. Por isto, ela insiste:

$\mathrm{Eu}$ vos peço e rogo com insistência, como a meus filhos muito queridos (cfr. 1 Cor 4,14), que persevereis naquilo que começastes por inspiração do Espírito Santo, sem abandonar vossa perfeição, como alguns costumam fazer, mas, escapando de todas as ciladas das trevas, esforçai-vos sempre pelo que é mais perfeito. Altíssima é a vossa perfeição (Com, 65).

Ela sabe quão difícil é o que eles propõem, por isto os encoraja a se manterem perseverantes nos seus propósitos iniciais, isto é dos primeiros tempos. Era isto que os frades zelosos da observância da Regra estavam se esforçando para viverem e por conta da sua resistência em abraçar uma vida mais cômoda, estavam sofrendo perseguições diversas por parte de Frei Elias e de seus sequazes. Então, entendemos que tais palavras bem podem ter sido dirigidas a eles, encorajando-os a se manterem perseverantes. Eles, de fato, atualizavam no seu tempo as ações dos apóstolos dos mártires e dos confessores:

Os Apóstolos ao verem que é renovada sua forma de vida, que sua doutrina é pregada, e que por vós são demonstrados exemplos da santidade especial. Alegram-se os mártires vendo que, pela efusão do sangue sagrado, sua constância está sendo apresentada de novo. Saltam de alegria os confessores, porque sabem que em vós rememora-se frequentemente a sua vitória sobre o inimigo (Com, 68).

Por fim, ela os abençoa: 
Recebei humildemente a graça que vos é oferecida, usando-a sempre dignamente em tudo para o louvor, a glória e a honra (cfr. Ap 4,9.11) daquele que morreu por vós, Jesus Cristo, Senhor nosso, que com o Pai e o Espírito Santo, vive e reina, vence e impera, Deus eternamente glorioso, por todos os séculos dos séculos. Amém” (Com, 69).

Ao abençoar os frades que se propunham e que se esforçavam para viver a mais autêntica pobreza, a Senhora Pobreza, dá-lhes o seu aval de contentamento com eles e os coloca sob o olhar divino, fonte de graça e de vida abundante. Viver esta intimidade com Deus era a aposta do grupo dos zelanti.

\section{CONSIDERAC̣ÕES FINAIS}

O documento analisado apresentou, no seu interior, aspectos literários, místicos e religiosos que retrataram a caminhada de São Francisco, marcada pelo seu enamoramento pela Senhora Pobreza e pela pregação do Evangelho. Fazendo amplo uso da intertextualidade, o autor anônimo, exalta os zelanti, que pretendiam manter o modo de vida heróico, dos primeiros tempos do Franciscanismo, enquanto critica aqueles que se acomodaram à uma vida mais prudente e mais relaxada: “[...] finalmente levantaram-se entre nós aqueles que não eram dos nossos, certos filhos de Belial, falando coisas vãs, operando coisas iníquas, dizendo-se pobres, quando não eram" (Com, 38). Assim, o autor enaltece os frades zelosos e critica os relapsos.

Podemos, então, concluir que o Sacrum Commercium é uma obra de literatura espiritual e uma "arena”, aonde, se trava um duelo literário, embasado na intertextualidade com as Sagradas Escrituras, a fim de enaltecer a virtude da pobreza e garantir que a mesma fosse mantida entre os frades menores, visando corrigir aqueles frades que estavam aderindo à Prudência e à Discrição, relaxando na observância da Regra e mudando os rumos que São Francisco havia proposto para si e para os seus seguidores.

Apesar de escrito alguns séculos atrás Este tema continua atual. Vale lembrar que, na atualidade, a Igreja Católica vem recebendo críticas em relação à sua riqueza e à perda de sua autoridade, situação que muito possivelmente levou à renúncia do papa Bento XVI. Não por acaso, o novo papa tomou o nome de Francisco, coisa inédita na História. A escolha do nome de Francisco tem demonstrado que se trata de um programa de 
governo e na proposta de uma reforma no pensamento e nos modos de construção de uma nova Igreja. Uma proposta de retorno à trajetória de Jesus Cristo, que viveu pobre e entre os pobres. 


\section{Title: The Commercium Sacrum or the alliance of San Francisco with the Lady Poverty}

\section{Abstract}

The present work had as objective to analyze the "Commercium Sacrum" document. The author is anonymous, to which the criticism assigns to a more erudite Franciscan of the 13th century or beginning of the 14th century. The work presents lover Francisco of the Poverty, to whom welcomes as queen of the virtues. It was verified that the author used widely the intertextuality resource, which is proven by the various biblical references taken from Jó, Sao Paulo letter to the Romans, Acts of the Apostles and Mateus Gospel. The author anonymous exalts the zelanti and his life mode to the same time that makes this literary "game", while criticizes those who accepted a cautious and relaxed life.

Keywords: Mendicant Hagiography; Saint Francis of Assisi; Literature. 


\section{REFERÊNCIAS}

BOLTON, Brenda. A Reforma na Idade Média. Trad. Maria da Luz Veloso.

Lisboa: Edições 70, 1983.

DUBY, G., A Idade Média idade dos homens. Do amor e outros ensaios. Trad. J. B. Neto. S. Paulo: Cia das Letras, 1989.

DUARTE, Teresinha. Arautos da Paz e Bem: Os franciscanos em Portugal (1214-1336). 2004. 464f. Tese (Doutorado em História). Instituto de Ciências Humanas, Universidade de Brasília, Braślia, 2004.

FALBEL, Nachman. Os espirituais franciscanos. São Paulo: Perspectiva, 1995.

LEGENDA Perusina. In. São Francisco de Assis. Escritos e biografias de São Francisco de Assis. Crônicas e outros testemunhos do primeiro século franciscano. 3. Ed. Petrópolis. Vozes: CEFEPAL. 1983. p. 727-846.

GRÉGOIRE, R. L'adage ascétique Nudus nudum Cristum sequi, in Studi Storici in on'Ure di $\mathbf{0 .}$ Bertolini. Pisa: 1972, t. I, p. 395-409.

SACRUM Commercium. In. Fontes Franciscanas Edição de Bolso. Santo André/SP: 0 mensageiro de Santo Antônio, 2012. Edição de Bolso VI. 5.

VAUCHEZ, André. A Espiritualidade da Idade Média Ocidental Séc. VIII - XIII. Trad. Teresa Antunes Cardoso. Lisboa: Editorial Estampa, 1995.

VIEIRA, Carlos José. A Imagem de São Francisco construída pela Legenda dos Três Companheiros: 0 Alter Christus. Monografia de Final de Curso. Catalão: UFG, 2008. 